\title{
Thermo-mechanical analysis of mass concrete elements made of rubberized concrete
}

\section{Análise termo-mecânica de um elemento de concreto massa produzido em concreto com borracha}
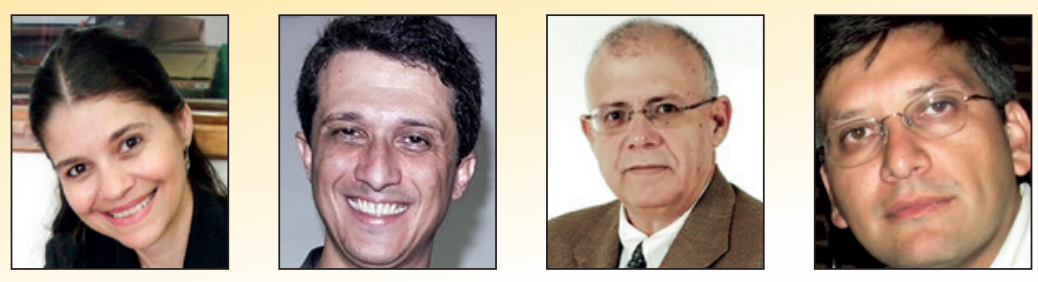

\author{
A. C. ALBUQUERQUE \\ alberia.albuquerque@cba.ifmt.edu.br \\ https://orcid.org/0000-0002-9697-8075 \\ S. B. DOS SANTOS \\ sergio botassi@yahoo.com.br \\ https://orcid.org/0000-0002-4875-7147 \\ J. L. CALMON c \\ calmonbarcelona@gmail.com \\ https://orcid.org/0000-0002-3054-4784 \\ L. C. P. DA SILVA FILHO b \\ Icarlos66@gmail.com.br
} https://orcid.org/0000-0003-3703-7328

\begin{abstract}
In this study, mass concrete samples with tire rubber chips (rubberized concrete) were evaluated in order to determine if the addition of rubber particles would enhance cracking strength due to volumetric variations of thermal origin, compared to a reference concrete, without rubber. Samples of the concretes studied were initially tested to characterize their thermal and mechanical properties. The test results were used as parameters for the analysis of the thermo-mechanic behavior of the rubberized concrete by means of a software that determined the thermal and stress response on a bi-dimensional dominion of a structural element of hypothetical geometry, typical of dam construction, applying FEM (finite element method) analysis. The results obtained indicated that, although the maximum temperatures expected are similar for both concretes (reference and rubberized), those containing tire rubber chips are subjected to lower tensile stresses, about half the stress generated in the control concrete. This behavior indicates that the addition of tire rubber chips in concrete is an efficient strategy to minimize the risk of cracking due to thermal stresses.
\end{abstract}

Keywords: mass concrete, tire rubber, thermal stress analysis, finite element method.

\section{Resumo}

Neste estudo, foram avaliadas amostras de concreto massa com borracha (concreto emborrachado) para determinar se a adição de partículas de borracha aumentaria a resistência à fissuração devido a variações volumétricas de origem térmica, em comparação com um concreto de referência, sem borracha. Amostras dos concretos estudados foram inicialmente testadas para caracterizar suas propriedades térmicas e mecânicas. Os resultados do teste foram utilizados como parâmetros para a análise do comportamento termo-mecânico do concreto emborrachado por meio de um software que determinou a resposta térmica e de tensões em um domínio bidimensional de um elemento estrutural de geometria hipotética, típico da construção de barragens, aplicando análise FEM (método dos elementos finitos). Os resultados obtidos indicaram que, embora as temperaturas máximas esperadas sejam similares para ambos os concretos (referência e emborrachado), aqueles contendo partículas de borracha são submetidos a menores esforços de tração, cerca de metade da tensão gerada no concreto de controle. Esse comportamento indica que a adição de partículas de borracha de pneus no concreto é uma estratégia eficiente para minimizar o risco de fissuração devido a tensões térmicas.

Palavras-chave: concreto massa, borracha de pneu, análise de tensão térmica, método de elementos finitos. 


\section{Introduction}

The use of tire particles mixed in concrete, forming a composite known as rubberized concrete, has received increasing attention from several research groups ${ }^{1-7}$. This interest can be justified both because this seems to be an useful alternative for the disposal of this kind of residue, and because it is looking to be an interesting strategy to modify the properties of concretes to meet the specific requirements demanded by some special applications, where thermal and acoustic isolation, or high tenacity, are relevant properties. Despite the fact that concretes with tire rubber tend to present lower compressive and tensile strengths, they have a greater deformation capacity and less fragile behavior in fracture, indicating a higher capacity of energy absorption compared to conventional concretes. This behavior is attributed to the capacity of rubber, as an aggregate, of enduring greater elastic strains before the final fracture of the composite ${ }^{1-4}$.

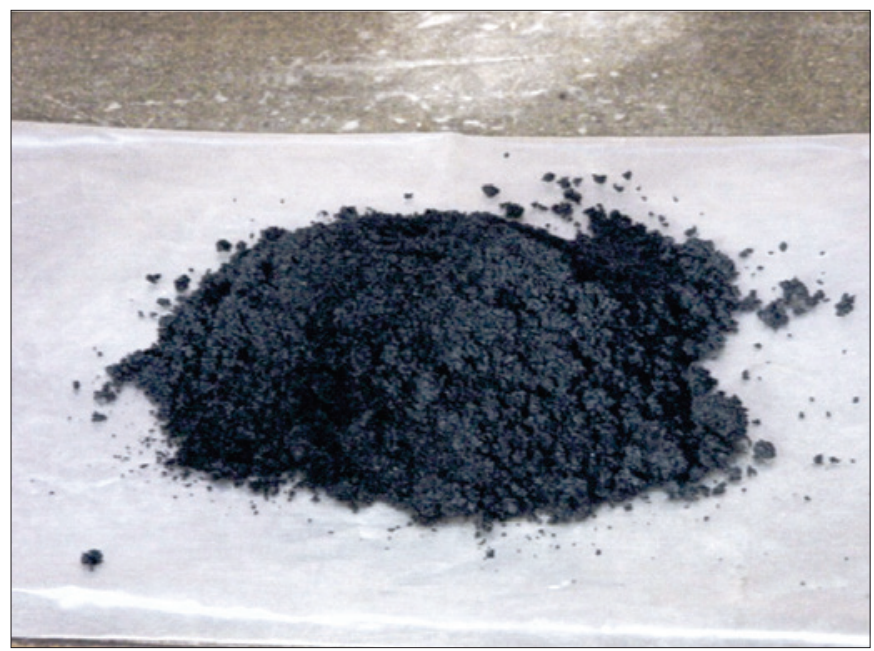

\section{Figure 1}

Visual aspect of tire particles in the form of granules

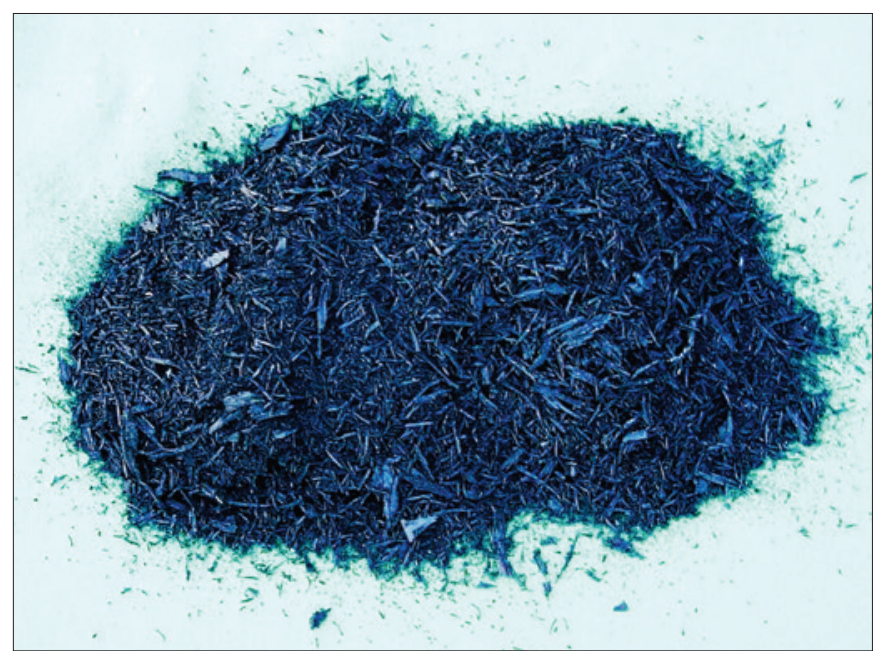

Figure 2

Visual aspect of tire particles in the form of fibers
The greater ductility and tenacity of the concretes made with tire rubber particles are especially interesting for the reduction of the risk of cracking in situations where the concrete is submitted to considerable and restrained volumetric variations due to thermal changes, such as with mass concrete elements. $\mathrm{ACl}$ defines mass concrete as: "any volume of concrete with dimensions large enough to require that measures be taken to cope with the generation of heat from hydration of the cement and attendant volume change to minimize cracking. The design of mass concrete structures is generally based on durability, economy, and thermal action, with strength often being a secondary concern." 5

This study is part of a larger research focused on the viability of incorporating tire particles in concrete, developed at the Technological Center of Civil Engineering at FURNAS Centrais Elétricas S/A, with the support of the National Electrical Energy Agency ANEEL, and the National Council for Scientific and Technological Development - CNPq/Brazil.
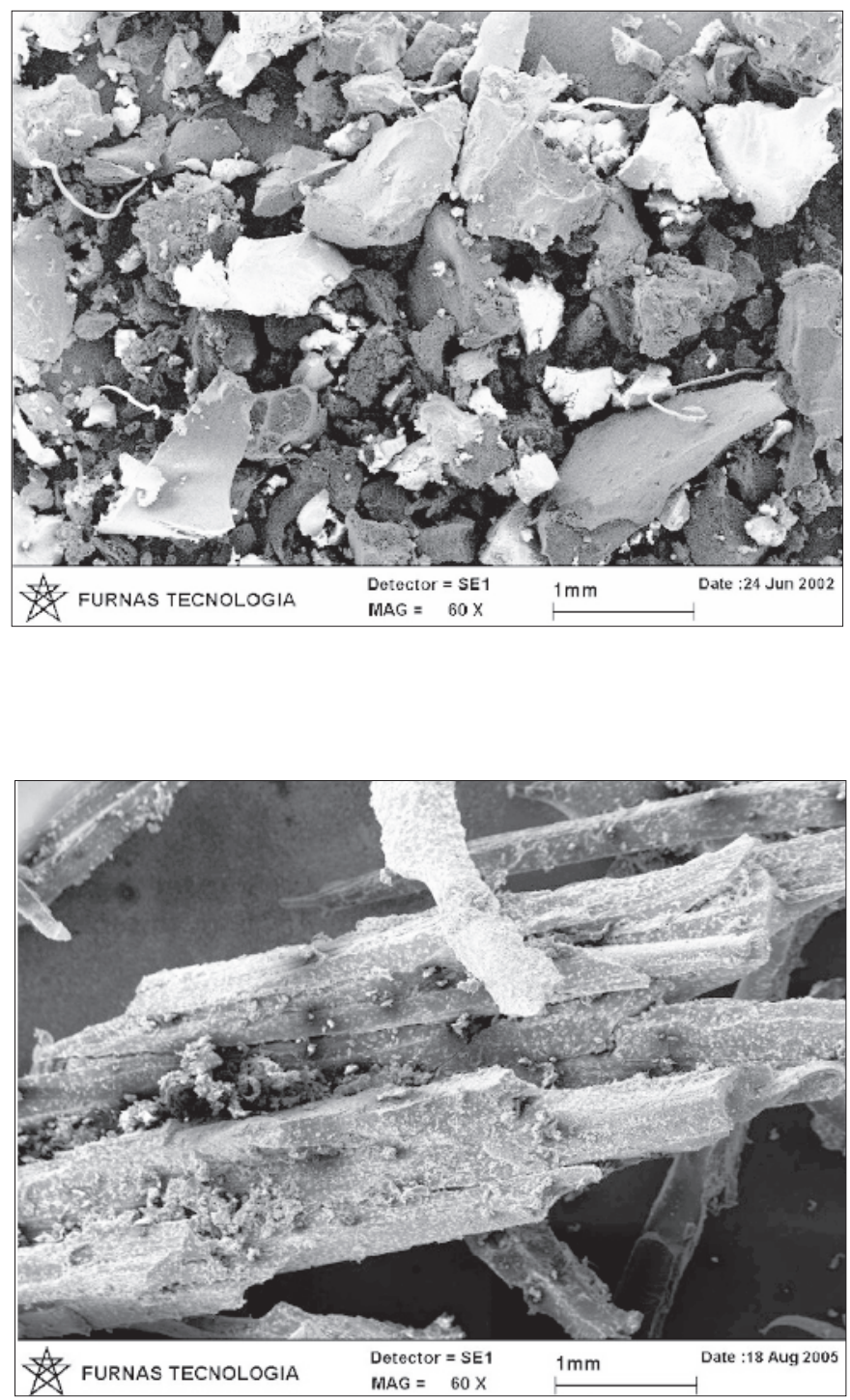


\section{Research significance}

The problem of cracking in mass concrete requires actions such as the selection of materials and/or processes that reduce the heat generated during the hydration of cement and the stresses generated while the material is cooling; or the increase of the deformation capacity of concrete. In this research, the use of tire particles was studied as an alternative to obtain beneficial changes in the thermal and viscoelastic properties of mass concrete samples, in order to reduce the risks of cracking due to thermal effects at early ages. The effect on a generic structural element was evaluated by means of a numerical simulation made using a software tool that employed the finite element method for a thermomechanical analysis. The results obtained are promising, because the thermal stresses on the rubberized concrete would develop more slowly, allowing time for the concrete to increase its tensile strength.

\section{Experimental procedure}

The study was carried out on concrete samples made with cement contents close to $310 \mathrm{~kg} / \mathrm{m}^{3}\left(354 \mathrm{lb} / \mathrm{jd}^{3}\right)$ and a water/cement ratio of 0.492 . Three mixes were cast: a reference or control concrete (CC), a concrete with $10 \%$ of tire particles in granules (CG), and a third concrete containing $10 \%$ of elongated tire particles, constituting small fibers $(\mathrm{CF})^{6}$. Figures 1 and $\mathbf{2}$ show the visual aspect of the tire particles obtained in the form of granules and fibers, respectively. These particles were applied in the CG and CF concrete mixes as a partial replacement of the fine aggregate (sand) volume fraction. In the control mix, it was necessary to use an airentraining agent in order to obtain the same amount of entrained air as measured in CG and CF mixes ${ }^{7}$. The characteristics of the materials used and the mix proportions for each concrete are described respectively in Tables 1 and 2 .

The analysis of the thermal behavior of an element made with these three types of concrete was done based on the results of previous tests conducted to determine the thermal conductivity coefficients, the thermal diffusion, the specific heat and the adiabatic rise of temperature of each concrete type ${ }^{6}$. The input parameters needed for the stress analysis included also the results of earlier

Table 1

Materials

\begin{tabular}{|c|c|}
\hline Material & Type \\
\hline Portland cement & $\begin{array}{c}\text { CP II F - } 32 \\
\text { (Ordinary Portland Cement with limestone filler) }\end{array}$ \\
\hline $\begin{array}{c}\text { Coarse aggregate - } \\
19 \mathrm{~mm} \text { (0.75 in.) and } 38 \mathrm{~mm} \text { (1.50 in.) }\end{array}$ & Crushed granite \\
\hline Fine aggregate & Natural sand \\
\hline Tire rubber particles & $\begin{array}{c}\text { Granules: nominal maximum size }=1.5 \mathrm{~mm}(0.06 \mathrm{in} .) \\
\text { Scraps (fibers): shape factor }=10 \\
\text { nominal fiber length }=10 \mathrm{~mm}(0.39 \mathrm{in} .)\end{array}$ \\
\hline
\end{tabular}

\section{Table 2}

Mixture proportions

\begin{tabular}{|c|c|c|c|c|c|c|c|}
\hline \multicolumn{2}{|c|}{ Mixtures } & \multicolumn{2}{|c|}{ Control (CC) } & \multicolumn{2}{|c|}{$10 \%$ granules (CG) } & \multicolumn{2}{|c|}{$10 \%$ fibers $(\mathrm{CF})$} \\
\hline \multirow{8}{*}{$\begin{array}{l}\text { Composition } \\
\text { data } \\
\left(\mathrm{kg} / \mathrm{m}^{3}\right) \\
\left(\mathrm{lb} / \mathrm{jd}^{3}\right)\end{array}$} & Portland cement & 307 & $(517)$ & 305 & $(514)$ & 309 & $(521)$ \\
\hline & Water & 151 & $(254)$ & 150 & $(252.8)$ & 152 & $(256)$ \\
\hline & Natural sand & 626 & $(1055)$ & 560 & $(943.9)$ & 567 & (956) \\
\hline & Rubber & $(-)$ & $(-)$ & 28.3 & $(47.7)$ & 28.7 & $(47.7)$ \\
\hline & $\begin{array}{l}19 \text { mm crushed } \\
\text { aggregate }\end{array}$ & 535 & (902) & 531 & (895) & 538 & $(907)$ \\
\hline & $\begin{array}{c}38 \text { mm crushed } \\
\text { aggregate }\end{array}$ & 681 & $(1148)$ & 676 & $(1139)$ & 685 & $(1154)$ \\
\hline & $\begin{array}{l}\text { Superplasticizer } \\
\text { admixture }\end{array}$ & 0.460 & $(0.775)$ & 0.520 & $(0.876)$ & 0.618 & $(1.042)$ \\
\hline & $\begin{array}{l}\text { Air entraining } \\
\text { admixture }\end{array}$ & 0.092 & $(0.155)$ & $(-)$ & $(-)$ & $(-)$ & $(-)$ \\
\hline \multirow{7}{*}{$\begin{array}{l}\text { Properties } \\
\text { of fresh } \\
\text { concrete }\end{array}$} & W/C ratio & 0.492 & $(-)$ & 0.492 & $(-)$ & 0.492 & $(-)$ \\
\hline & $\begin{array}{l}\% \text { mortar with } \\
\text { entrained air }\end{array}$ & 54.0 & $(-)$ & 54.4 & $(-)$ & 53.8 & $(-)$ \\
\hline & Fineness module & 5.783 & $(-)$ & 5.836 & $(-)$ & 5.846 & $(-)$ \\
\hline & $\%$ sand in mass & 34 & $(-)$ & 33 & $(-)$ & 33 & $(-)$ \\
\hline & Slump (mm) (in) & 40 & $(1.57)$ & 40 & $(1.57)$ & 35 & $(1.38)$ \\
\hline & Entrained air (\%) & 4.6 & $(-)$ & 4.6 & $(-)$ & 3.8 & $(-)$ \\
\hline & $\begin{array}{l}\text { Specific gravity } \\
\left(\mathrm{kg} / \mathrm{m}^{3}\right)\left(\mathrm{lb} / \mathrm{jd}_{3}\right)\end{array}$ & 2292 & $(3863)$ & 2267 & $(3821)$ & 2304 & (3883) \\
\hline
\end{tabular}


Table 3

Average results of thermal and mechanical properties tests ${ }^{6}$

\begin{tabular}{|c|c|c|c|c|c|c|c|}
\hline \multicolumn{2}{|c|}{ Mixtures } & \multicolumn{2}{|c|}{$\mathrm{CC}$} & \multicolumn{2}{|c|}{ CG } & \multicolumn{2}{|c|}{$\mathrm{CF}$} \\
\hline \multirow{2}{*}{$\begin{array}{l}\text { Heat conductivity } \\
(\mathrm{J} / \mathrm{m} . \mathrm{s} . \mathrm{K})\left(\mathrm{W} / \mathrm{ft} .{ }^{\circ} \mathrm{F}\right)\end{array}$} & Average & 2.30 & $(0.39)$ & 2.28 & $(0.39)$ & 2.31 & $(0.39)$ \\
\hline & $\begin{array}{l}\text { Standard } \\
\text { deviation }\end{array}$ & 0.01 & $(0.002)$ & 0.01 & $(0.002)$ & 0.02 & $(0.003)$ \\
\hline \multirow{2}{*}{$\begin{array}{c}\text { Specific heat } \\
\text { (20\% sat). } \\
\text { (J/kg.K) (BTU/lb. }{ }^{\circ} \text { F) }\end{array}$} & Average & 963 & $(0.23)$ & 1031 & $(0.25)$ & 927 & $(0.22)$ \\
\hline & $\begin{array}{l}\text { Standard } \\
\text { deviation }\end{array}$ & 30 & $(0.007)$ & 72 & $(0.017)$ & 68 & $(0.016)$ \\
\hline \multirow{2}{*}{$\begin{array}{l}\text { Heat diffusivity } \\
\left(\mathrm{m}^{2} / \text { day }\right)\end{array}$} & Average & 0.098 & $(1.054)$ & 0.092 & $(0.989)$ & 0.094 & $(1.011)$ \\
\hline & $\begin{array}{l}\text { Standard } \\
\text { deviation }\end{array}$ & 0.003 & $(0.032)$ & 0.002 & $(0.022)$ & 0.001 & $(0.011)$ \\
\hline \multirow[b]{2}{*}{ Poisson's ratio } & Average & 0.22 & $(-)$ & 0.16 & $(-)$ & 0.22 & $(-)$ \\
\hline & $\begin{array}{l}\text { Standard } \\
\text { deviation }\end{array}$ & 0.01 & $(-)$ & 0.01 & $(-)$ & 0.01 & $(-)$ \\
\hline \multirow{2}{*}{$\begin{array}{l}\text { Thermal expansion } \\
\left(10-6 /{ }^{\circ} \mathrm{C}\right)\end{array}$} & Average & 11.09 & $(-)$ & 10.84 & $(-)$ & 11.19 & $(-)$ \\
\hline & $\begin{array}{l}\text { Standard } \\
\text { deviation }\end{array}$ & 0.31 & $(-)$ & 0.13 & $(-)$ & 0.01 & $(-)$ \\
\hline \multirow{2}{*}{$\begin{array}{l}\text { Compression strength } \\
\text { ( } 91 \text { days) }\end{array}$} & Average & 31.30 & $(-)$ & 26.45 & $(-)$ & 26.75 & $(-)$ \\
\hline & $\begin{array}{l}\text { Standard } \\
\text { deviation }\end{array}$ & 0.57 & $(-)$ & 0.35 & $(-)$ & 0.35 & $(-)$ \\
\hline
\end{tabular}

tests of compressive strength, Young's modulus, flexural strength, strain capacity, creep and thermal expansion ${ }^{6}$. Some of thermal and mechanic properties used in the thermodynamic analysis carried out in this study can be seen in Table 3 , while others, which vary in time, can be seen in Figures 3, 4, 5 and 6.

Based on the characteristics of the different concrete types studied, the thermo-mechanic behavior of a hypothetic element of mass concrete was analyzed. Because thermal stresses tend to be quite important in dam construction, the element chosen was a generic spillway wall, subject to the internal heat generated by cement hydration and exposed to environmental boundary conditions that allowed the heat to dissipate, resulting in a non-linear temperature gradient in the interior of the structure. The simulations were conducted with aid of the softwares PFEM_2DT and PFEM_2DAT 8 , which are able to determine the thermal and stress response,

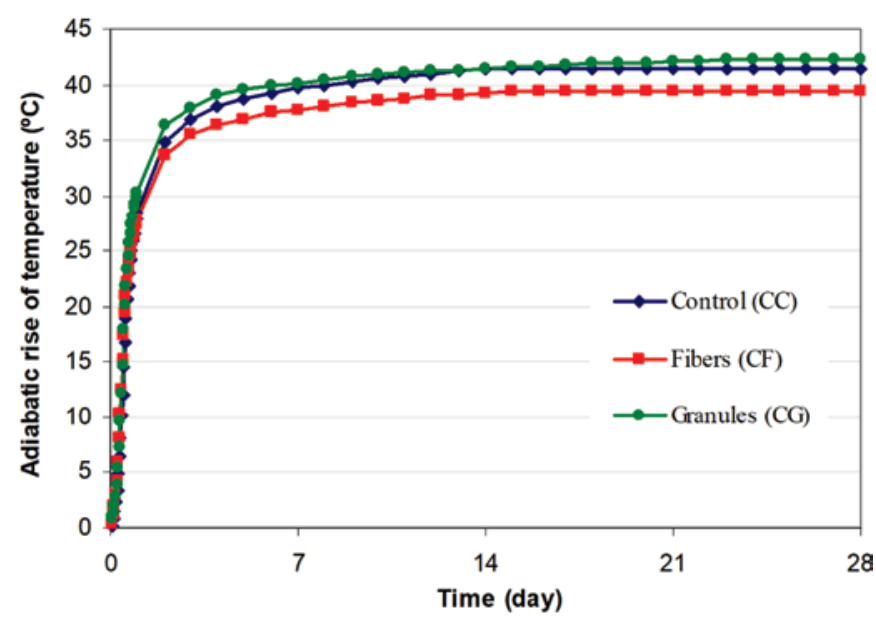

Figure 3

Adiabatic rise of temperature for each type of concrete respectively, in bi-dimensional dominions of any geometry, using the finite element method. In Fig. 7, the transversal section of the analyzed concrete element, and the respective mesh of finite elements employed can be observed.

The softwares PFEM_2DT and PFEM_2DAT consider that the construction process is carried out by adding layers of material, which is typical of dam construction operations. The PFEM_2DAT software, which has an object-oriented architecture, makes a linear and uncoupled viscoelastic thermo-mechanic analysis of the problem. The results are integrated with the thermal analysis made by the PFEM_2DT software, in an incremental way, in order to obtain the complete solution for the strain and stress vectors derived from the thermal gradients generated by the thermal analysis software.

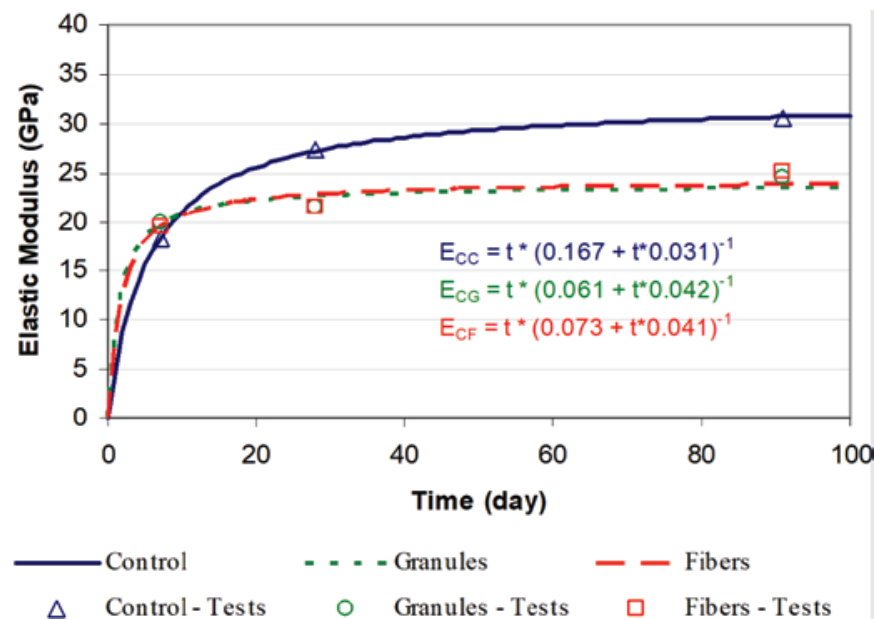

$\triangle$ Control-Tests $\bigcirc$ Granules - Tests $\square$ Fibers - Tests

\section{Figure 4}

Experimental data points and best-fit curve of the Young's modulus evolution over time for each type of concrete 


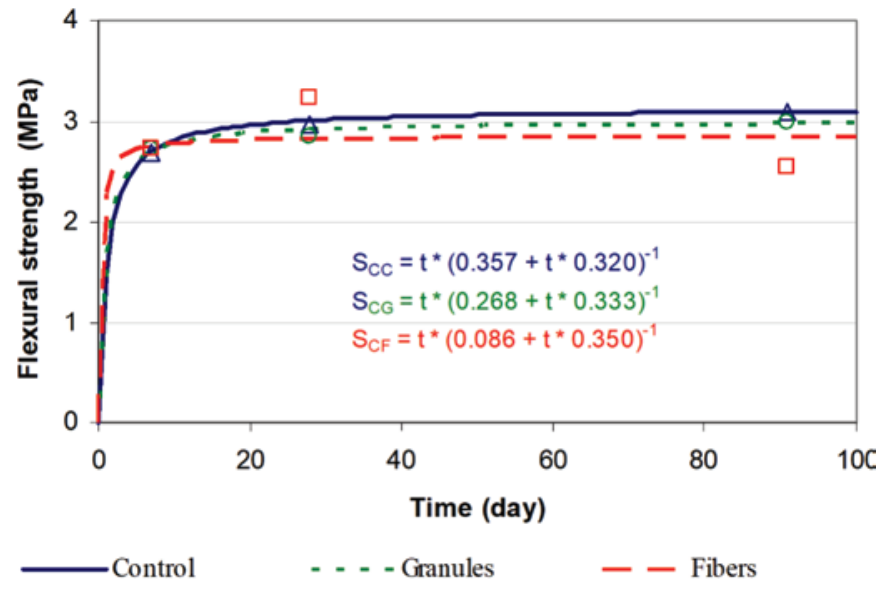

$\Delta$ Control-Tests $\bigcirc$ Granules - Tests $\square$ Fibers - Tests

\section{Figure 5}

Experimental data points and best-fit curve of the flexural strength evolution over time for each type of concrete in bending tests

These tools also consider the time dependent effects, according to prediction models based on the creep function suggested by the Bureau of Reclamation ${ }^{9}$ and the creep coefficient given by $\mathrm{ACl}^{10}$, as well as drying shrinkage parameters recommended by $\mathrm{CEB}^{11}$ and Bazant ${ }^{12}$. The software used have already been validated in different applications involving dam and foundation structures ${ }^{8,13}$. For each concrete type - CC, CG and CF - the thermal simulations were done according to the conditions and hypothesis described in Table 4. Taking into account the capabilities of the PFEM_2DT software, the simulation considered that the concrete was poured in $3 \mathrm{~m}$ thick layers with an interval of 2 days between layers. This situation is common in massive structures like those found in dam construction ${ }^{14,15}$.

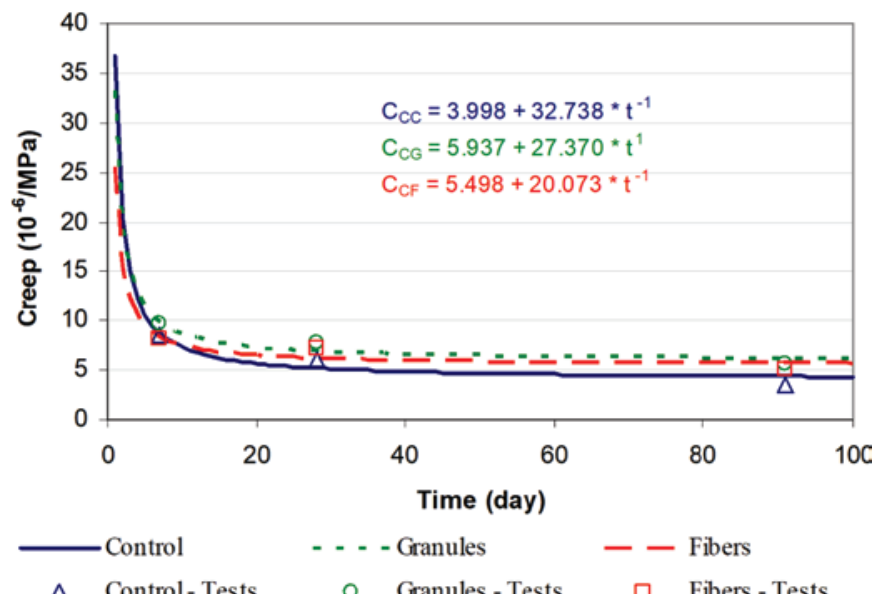

$\triangle$ Control-Tests $\quad \circ$ Granules - Tests $\square$ Fibers - Tests

\section{Figure 6}

Experimental data points and best-fit curve of the creep evolution over time for each type of concrete

Given the fact that the thermal evaluation alone is not sufficient to evaluate the risk of thermal cracking, the temperature distribution on the element was used to calculate the stresses in the PFEM_2DAT software. The temperature data was transposed to a strain field distribution to determine the possibility of cracking, using the mechanical properties of the concretes obtained in previous tests, as explained above.

\section{Results and discussion}

\subsection{Thermal analysis}

As widely known, heat transfer in solids occurs due to the
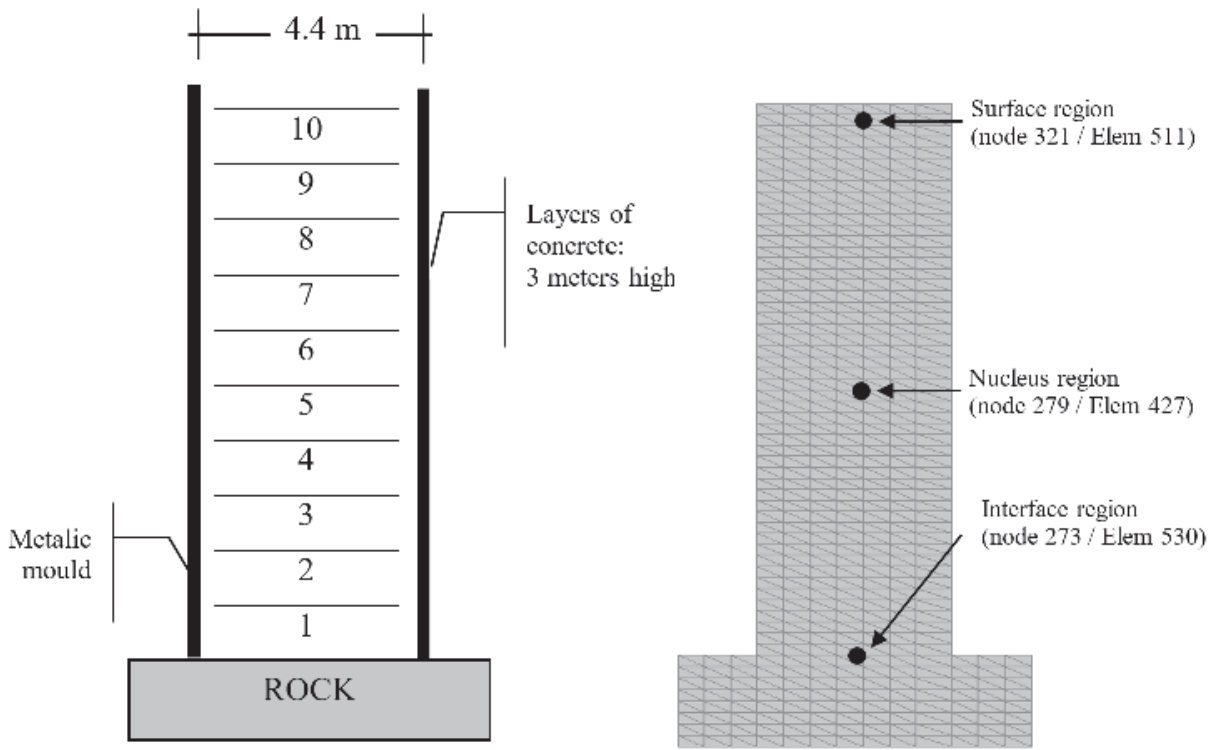

Figure 7

Cross-section and finite element mesh adopted of the generic concrete element analyzed 


\section{Table 4}

Executive conditions

\begin{tabular}{|c|c|c|c|}
\hline Executive conditions & Field conditions & Characteristcs of rock & Computer simulation data \\
\hline $\begin{array}{l}\text { - Layers of } 3 \mathrm{~m}(9,84 \mathrm{ft}) \\
\text { placed each } 2 \text { days. } \\
\text { Total } 30 \mathrm{~m}(98,4 \mathrm{ft}) \text { high } \\
\text { (10 layers) } \\
\text { - Wet cure } \\
\text { - Metalic moulds } \\
\text { - Temperature of fresh } \\
\text { concrete }=22^{\circ} \mathrm{C}\left(72^{\circ} \mathrm{F}\right)\end{array}$ & $\begin{array}{l}\text { - Convection coefficient: } \\
25 \mathrm{~W} / \mathrm{m}^{2}{ }^{\circ} \mathrm{C}\left(4.4 \mathrm{BTU} / \mathrm{h} . \mathrm{ft} 2 .{ }^{\circ} \mathrm{F}\right) \\
\text { - Atmospheric average } \\
\text { temperature: } 22^{\circ} \mathrm{C}\left(72^{\circ} \mathrm{F}\right)\end{array}$ & $\begin{array}{l}\text { THERMAL PrOPERTIES } \\
\text { - Initial temperature }=22^{\circ} \mathrm{C}\left(72^{\circ} \mathrm{F}\right) \\
\text { - Heat conductivity: } 2,303 \mathrm{~J} / \mathrm{m} . \mathrm{s} . \mathrm{K} \\
\left(0.39 \mathrm{~W} / \mathrm{ft} .{ }^{\circ} \mathrm{F}\right) \\
\text { - Specific gravity: } 2400 \mathrm{~kg} / \mathrm{m}^{3} \\
\left(4045 \mathrm{lb} / \mathrm{jd}^{3}\right) \\
\text { - Specific heat: } 1006 \mathrm{~J} / \mathrm{kg}^{\circ}{ }^{\circ} \mathrm{C} \\
\\
\text { MECHANICAL PrOPERTIES } \\
\text { - Young's modulus: } 32 \mathrm{GPa} \\
\text { (4641 ksi) } \\
\text { - Coefficient of thermal } \\
\text { expansion: } 11,09 \times 10^{-6} /{ }^{\circ} \mathrm{C} \\
\text { - Poisson's ratio: } 0,22\end{array}$ & $\begin{array}{l}\text { - Total number of elements: } 908 \\
\text { - Total number of nodes: } 526 \\
\text { - Time of analysis: } 2400 \mathrm{~h} \\
\text { - Time step: } 4 \mathrm{~h} \\
\text { - Average element size: } \\
\text { 0,6m (1.97 ft) } \\
\text { - FEM element: triangular with } \\
3 \text { nodes }\end{array}$ \\
\hline
\end{tabular}

transmission of energy from one region to another that has a different temperature, and the phenomenon has a speed proportional to the temperature gap between these regions. The heat in the interior of the structural element and in its vicinity dissipates following the three basic mechanisms for heat transfer: conduction, convection, and radiation. In a mass concrete structure, the heat liberated during cement hydration causes a sharp rise in concrete temperature at its core, while heat is lost at the surface, resulting in a cooling gradient that may result in substantial thermal stresses. Considering these behavioral aspects and the thermal properties of the different concretes tested, it was possible to arrive, by means of the computer simulations performed, at the probable range of temperatures that would be established in the cross section of the generic element taken as an example in this study. The diagram of the isotherms presented in Fig. $\mathbf{8}$ shows the temperature gradient generated between the surface and the core of such structure, for each of the different concretes studied.

It is noticeable that the temperatures vary, approximately, from $25^{\circ} \mathrm{C}\left(77^{\circ} \mathrm{F}\right)$ in the regions closer to the contact with the rockbed (node 273), and on the surface of concrete (node 321), reaching up to $60^{\circ} \mathrm{C}\left(140^{\circ} \mathrm{F}\right)$ in the core of the structure (node 279$)$. The thermal gradients obtained are similar for the reference concrete and those with tire particles. This behavior was expected, given that the concretes showed similar thermal properties (see Fig. 3 and Table 3).

Nonetheless, the statistical analysis of the experimental data related to the basic characterization of concretes indicated that there is a significant lower thermal conductivity and higher adiabatic rise of temperature in concrete $\mathrm{CG}^{6}$. This might explain why the element using data from concrete with rubber granules - CG -

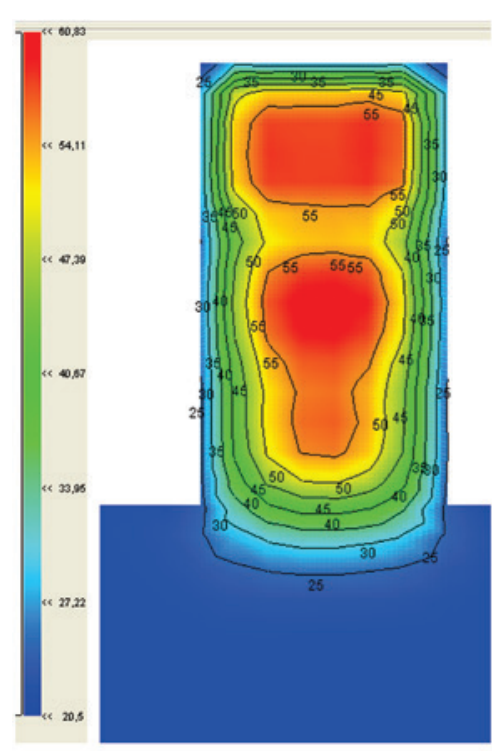

(a)

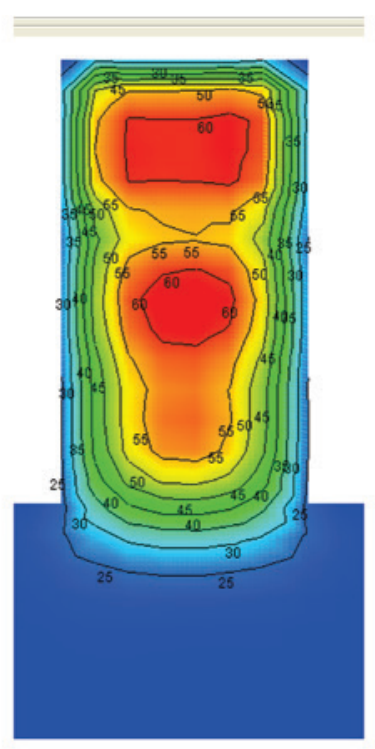

(b)

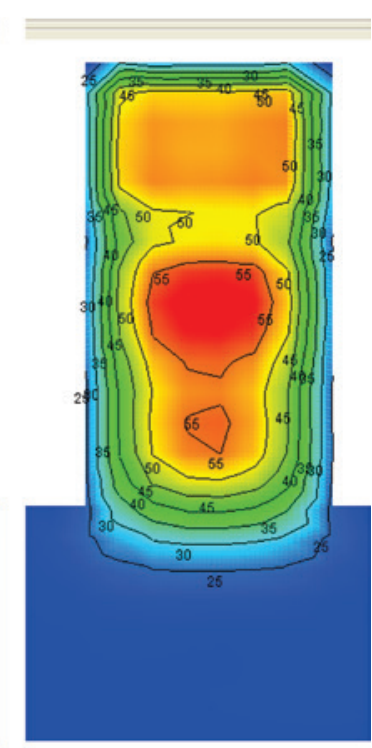

(c)

\section{Figure 8}

Isotherm plots showing the temperature gradients from surface to core of (a) reference concrete (CC) after 144h, (b) concrete with tire granules (CG) after 128h, and (c) concrete with tire fibers (CF) after $144 \mathrm{~h}$ 
presented a temperature field with slightly higher values in the regions close to the concrete-bedrock interface, at the structure's core and near the surface, reaching maximum temperature values of $53.5^{\circ} \mathrm{C}\left(128^{\circ} \mathrm{F}\right), 62.5^{\circ} \mathrm{C}\left(145^{\circ} \mathrm{F}\right)$, and $54.5^{\circ} \mathrm{C}\left(130^{\circ} \mathrm{F}\right)$, at 2,6 and 20 days, respectively. The concrete with rubber fibers - CF - attained the lowest temperature values, of $50.5^{\circ} \mathrm{C}\left(123^{\circ} \mathrm{F}\right), 59.5^{\circ} \mathrm{C}$ $\left(139^{\circ} \mathrm{F}\right)$, and $51.5^{\circ} \mathrm{C}\left(125^{\circ} \mathrm{F}\right)$ at 2,6 and 20 days. The reference concrete - CC - assumed an intermediate behavior (Fig. 9). This thermal behavior is consistent with the results of the tests of adiabatic rise of temperature, which resulted in higher values for the CG concrete and lower ones for the CF concrete.

For all concretes, at the core of the generic elements analyzed, due to the overlapping of concrete layers and the distance from the surface, the heat production is greater than the dissipation capacity, at early ages, thus the temperature only stabilizes after approximately 70 days. The short pouring interval between concrete layers does not allow the complete cooling of the precedent layer and the heat transfer is slow due to the smaller thermal gradient. Thus, the maximum temperatures occur at relatively early ages, and the temperature reaches higher values, taking longer than the outer regions to stabilize.

On the contrary, in the outer regions, at the concrete-bedrock interface or near the concrete surface, the heat production rate is smaller than the dissipation capacity. Consequently, the curve of temperature evolution reaches lower maximum values than at the core. At early ages, the heat generated in these regions, or transferred from the core, is rapidly dissipated to the neighboring environment, which has lower temperatures.

In time, the temperature of the top of the rock layer starts to rise, reducing the thermal gradient in the concrete-bedrock interface. Nevertheless, the thermal gradient remains quite large at the concrete surface, due to air renovation and the use of a metallic mould. For this reason, the cooling curves at the surface of the element are more pronounced and the temperature stabilizes after approximately 35 days, while at the concrete-bedrock interface, the stabilization occurs only after 60 days (Fig. 9(a) and 9 (c)).

\subsection{Stress analysis}

When the temperature rises, concrete expands proportionally to its thermal expansion coefficient. At early ages, the concrete microstructure is in a plastic state, and presents little restriction to this expansion. In time, however, concrete hardens and assumes a viscoelastic behavior, generating restrictions and causing the development of considerable compression stresses.

In mass concrete elements, the concrete continues to expand until the maximum temperature is reached. When it starts to cool, concrete contracts, relieving the compression stresses.

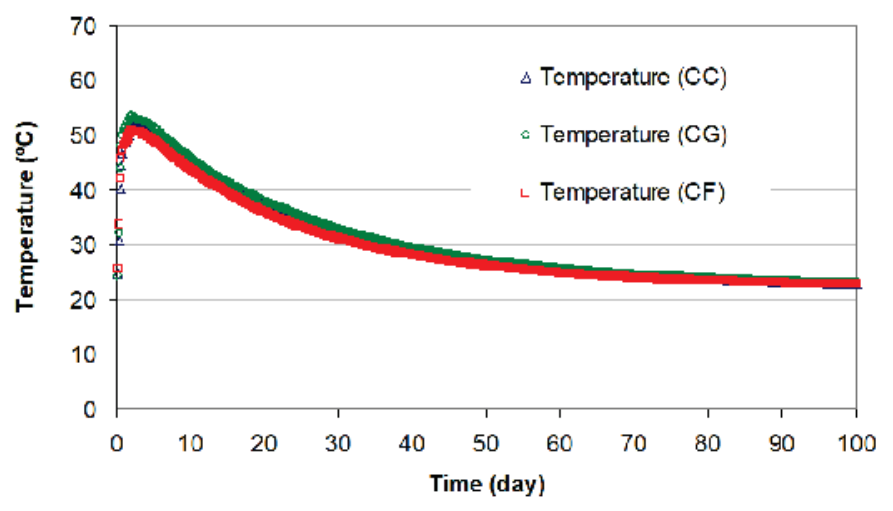

(a)

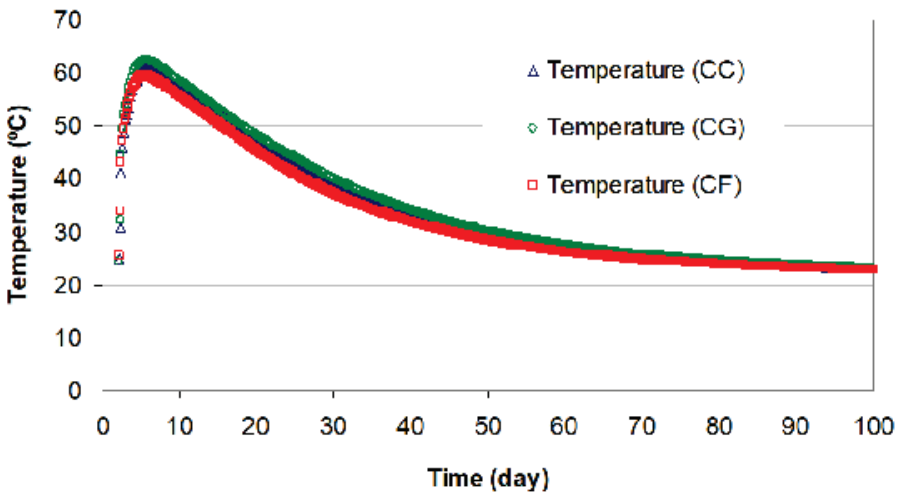

(b)

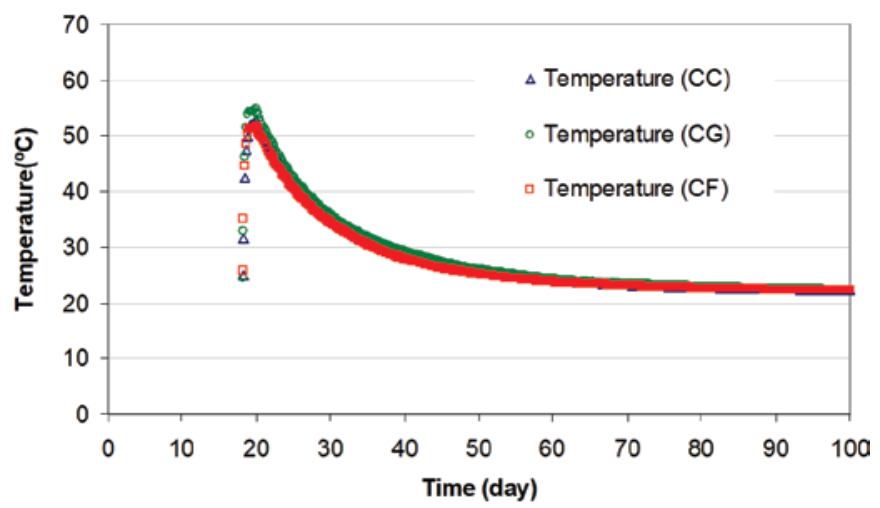

(c)

\section{Figure 9}

Temperature evolution: (a) at the concrete-bedrock interface (node 273); (b) at the core of the concrete element (node 279) and (c) at the surface of the concrete element (node 321) 


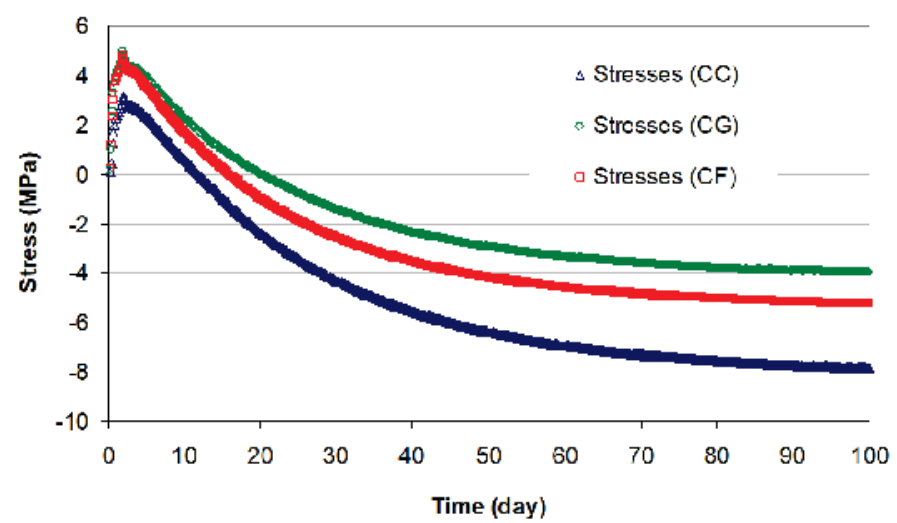

(a)

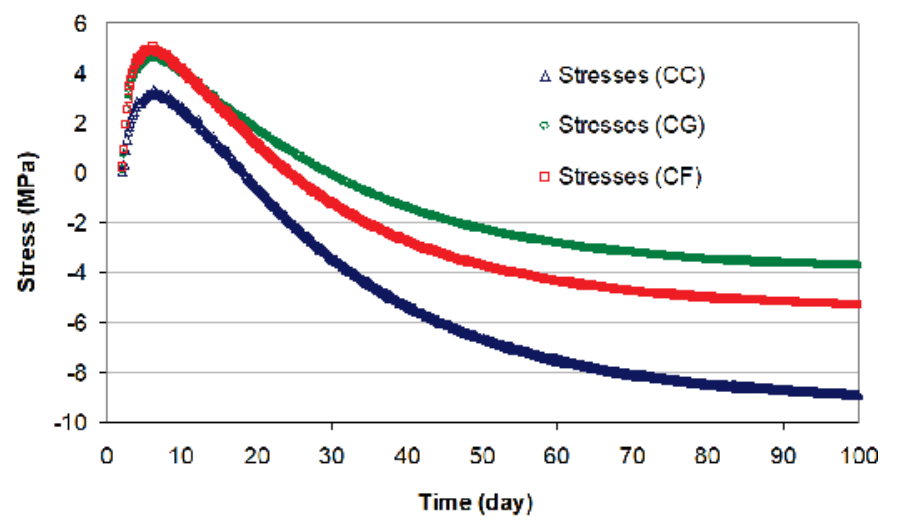

(b)

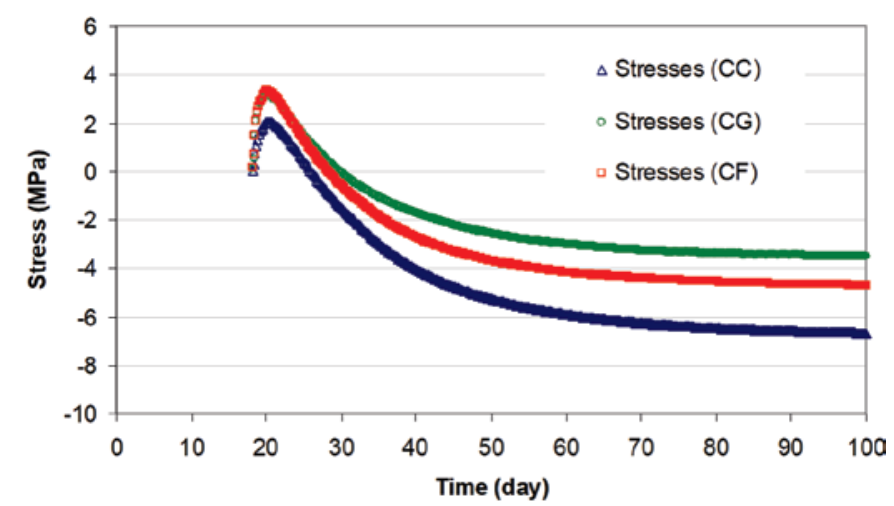

(c)

\section{Figure 10}

Evolution of tensile stresses: (a) at the concrete-bedrock interface (element 530); (b) at the core of the concrete element (element 427) and (c) at the surface of the concrete element (element 511)

This trend continues until the decline in temperature begins to generate tensile stresses, which become constant with the stabilization of the temperature. The differences in terms of evolution of temperatures and maximum normal stress for each concrete type tested can be observed in Fig. 9(a) and 10(a), Fig. 9(b) and 10(b), Fig. 9(c) and 10(c).

In spite of the fact that the distinct concrete mixes had similar thermal behavior, the thermo-mechanic analysis resulted in great differences in the stress values over time. In all three regions considered - next to the concrete-bedrock interface (Fig. 10(a)), at the element core (Fig. 10(b)), and on the concrete surface (Fig. 10(c)) - the CC concrete resulted in higher tensile stresses, up to twice those found in the CG concrete element, while the element made with CF concrete presented an intermediary behavior.

These results can be explained by the differences between the E-modulus and the creep values of the concretes studied, as presented in Fig. 4 and $\mathbf{6}$. The concretes with tire rubber had a smaller Young's modulus, $27 \%$ lower than that of the reference concrete; and presented higher creep, about $20 \%$ superior to that of the reference concrete, which allowed a better absorption of the strains, relieving tensile stresses. According to Mehta and Monteiro ${ }^{16}$, the lower the E-modulus, the smaller is the quantity of elastic tensile stress induced, at a given magnitude of shrinkage. Additionally, the larger the creep, the larger the stress relaxation will be, which also reduces the tensile stress. In Figure 11 a comparison is shown between the evolution of thermal stresses and the evolution of tensile strength for concrete types $\mathrm{CC}, \mathrm{CF}$, and $\mathrm{CG}$. It can be observed that, in all cases, the generated stress surpasses the tensile strength of the concrete. However, in the CC element, this occurs earlier (approximately on day 26) than in the elements made with concretes CF and CG (where it occurs on days 38 and 60 , respectively). This means that a situation of potential cracking due to thermal effects would occur in the CC concrete element earlier and with larger intensity than in the elements made with CF and CG concretes. In line with this fact, earlier studies on cracks evolution have found that composites made with a cementitious matrix reinforced with tire rubber particles demand more time to show cracks and, when it happens, the cracks tend to be finer, discontinuous and more evenly distributed. This behavior was attributed to the capacity of the rubber to absorb energy and deflect the original path of micro-cracks when these start to propagate on the interface between aggregates and cement paste $^{17,18}$. This way, rubber particles act to delay and reduce cracks, improving the deformation capacity of the material. 


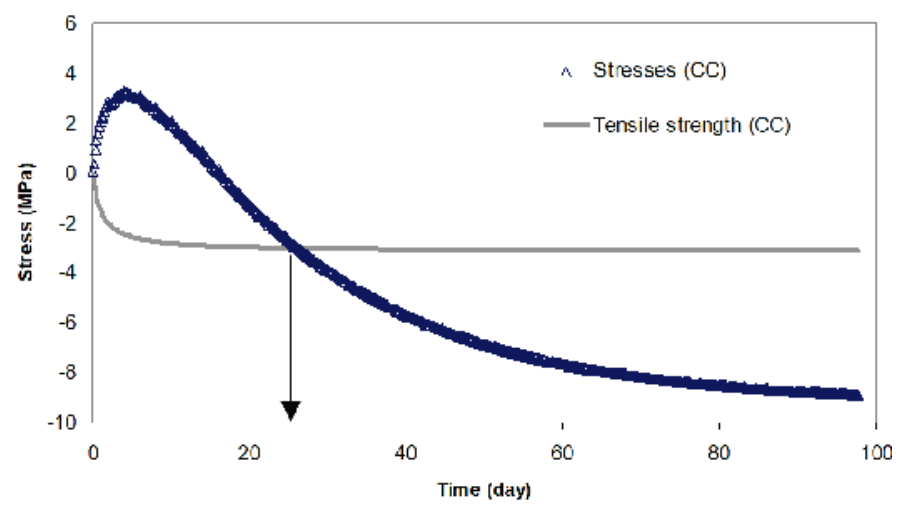

(a)

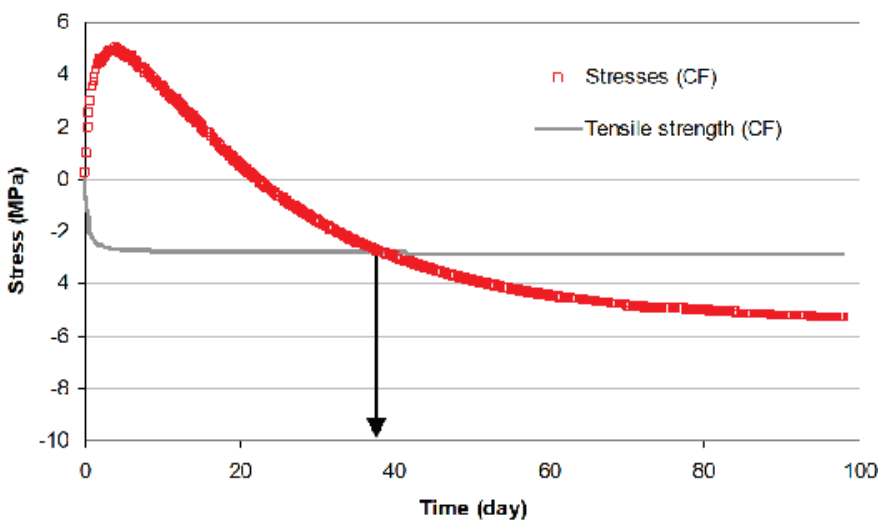

(b)

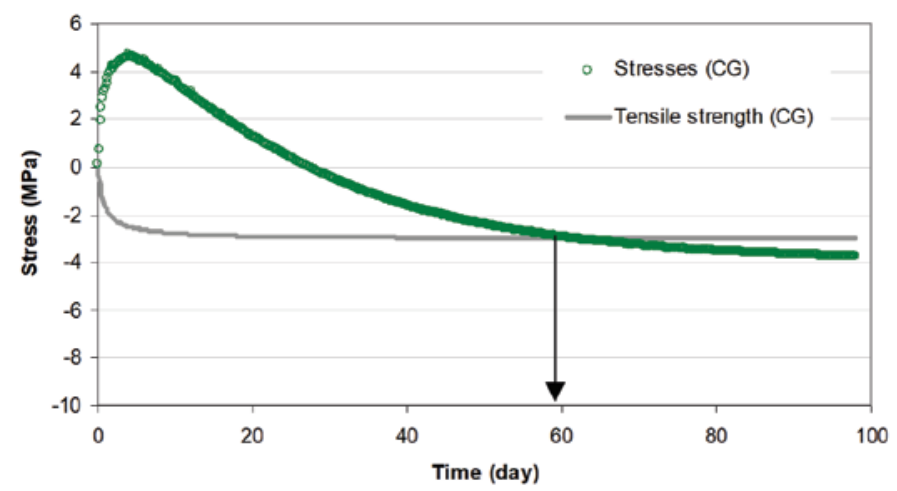

(c)

\section{Figure 11}

Evolution of thermal stresses versus tensile strength (element 427): (a) of concrete (CC); (b) of concrete (CF) and (c) of concrete (CG)

\section{Further research}

To corroborate the results obtained in this study, it is necessary to compare them with experimental results obtained monitoring real structures made with concretes similar to the CC, CG, and CF mixes studied here. In addition, it would be useful to make a thermo-mechanic analysis comparing control mixes of same compressive strength, with or without the addition of tire particles, to check the viability of replacing conventional concrete for rubberized concrete in some applications, with thermal gains and without any significant loss of structural efficiency.

\section{Conclusions}

Based on the thermo-mechanic analysis carried out in this work, the following conclusions could be drawn:

The thermal gradients and the temperature evolution of the reference concrete and the rubberized concretes tested are similar. Although the maximum temperature values found are similar for all concretes, those with tire rubber particles developed lower tensile stresses, about half of the ones found for the control concrete.

In the element made with the control concrete, the tensile stress generated by the temperature variation surpasses the tensile strength earlier than on the elements made with tire particles, increasing the risk of cracking.
The thermo-mechanic analyses carried out indicated that the use of concrete with tire rubber particles can be an efficient alternative to minimize the risk of thermal cracking, when compared with the control concrete.

Between the rubberized concretes, the risk of cracking was lower when particles in the form of granules were used.

\section{Acknowledgements}

The authors would like to thank FURNAS Centrais Elétricas S/A, specially the Concrete Laboratory Team, for technical support. Also thanks to ANEEL - National Electrical Energy Agency and CNPqBrasil - National Council for Scientific and Technological Development, for financial support.

\section{References}

1. Li, Z., Li, F., Li, J. S. L. ,"Properties of concrete incorporating rubber tire particles", Magazine of Concrete Research, V. 50, No. 4 , 1998, pp. 297-304.

2. Khatib, Z. K., Bayomy, F. M., "Rubberized Portland Cement Concrete", Journal of Materials in Civil Engineering, V. 11, No. 3, 1999, pp. 206-213. 
3. Topçu, I. B., "The properties of rubberized concretes", Cement and Concrete Research, V. 25, No. 2, 1995, pp. 304-310.

4. Toutanji, H. A., "The Use of Rubber Tire Particles in Concrete to Replace Mineral Aggregates", Cement and Concrete Composites, V. 18, No. 2, 1996, pp. 135-139.

5. $\mathrm{ACl}$ Committee 207. "Guide to Mass Concrete". ACI 207.1R05, 2005, 30p.

6. Albuquerque, A.C. "Studying mass concrete with tire rubber". PhD Dissertation - Federal University of Rio Grande do Sul (UFRGS), Brazil, 2009. (in Portuguese).

7. Albuquerque, A.C., Hasparyk, N.P., Andrade, M.A.S., Andrade, W.P. "Polymeric Admixtures as Bonding Agent between Tire Rubber and Concrete Matrix". ACl - Special Publication 229, Michigan/USA, v. 229, p. 479-496, 2005.

8. Santos, S.B. "A Contribution to the Study of thermomechanical behavior of mass concrete structures. Viscoelastic Linear Modeling and Applications". Masters Thesis. Brazil, Federal University of Espírito Santo, 2004. (in Portuguese)

9. U. S. BUREAU OF RECLAMATION. "Creep of concrete under high intensity loading" Concrete Laboratory Report NO C-820, Denver - Colorado, 1956.

10. ACI: AMERICAN CONCRETE INSTITUTE Committee $\mathrm{N}^{\circ}$ 209. "Prediction of creep, shrinkage, and temperature effects in concrete structures". Detroit, 1992.

11. CEB-FIP MODEL CODE: Comité Européen Du Béton - Federation Internationale de la Précontrainte. Bulletin d'Information $N^{\circ}$ 203.Vienne: 1991.

12. BAŽANT, Z. P. "Mathematical modeling of creep and shrinkage of concrete". In: $4^{\circ}$ RILEM International Symposium: creep and shrinkage of concrete, Illinois USA, 1987.

13. Santos, S. B.; et al. "Evaluation of results obtained by a voltage meter installed in a block of mass concrete and the values generated by the program PFEM_2DAT". In: $46^{\circ}$ Brazilian Congress of Concrete - Brazil, 2004. (in Portuguese)

14. Furnas Centrais Elétricas S.A. "Concrete: mass, structural, projected and roller compacted: testing and properties". Editor Walton Pacelli de Andrade - São Paulo: Pini, 1997. (in Portuguese)

15. Calmon, J. L. "Study of thermal and stress behavior in massive concrete structures. Application to the dams during the construction phase". PhD Dissertation - Universitat Politècnica de Catalunya (UPC), Barcelona, 1995. (in Spanish)

16. Mehta, P. K.; Monteiro, P. J. M. "Concrete: Structure, Properties and Materials". $2^{\text {nd }}$ Edition. New Jersey, EUA: Prentice Hall, 1994.

17. Turatsinze, A., Bonnet, S., Granju, J.-L. "Potential of rubber aggregates to modify properties of cement based-mortars: Improvement in cracking shrinkage resistance". Construction and Building Materials 21 (2007) 176-181.

18. Segre, N., Ostertag, C., Monteiro, P.J.M. "Effect of tire rubber particles on crack propagation in cement paste". Materials Research, Vol. 9, No. 3, 311-320, 2006. 